\title{
Chemical composition and rumen fermentation profile of mangrove leaves (Avicennia marina) from West Sumatra, Indonesia
}

\author{
NOVIRMAN JAMARUN ${ }^{1,2, \bullet}$, RONI PAZLA $^{1,3, \bullet \bullet}$, ARIEF $^{1}$, ANURAGA JAYANEGARA $^{4}$, GUSRI YANTI $^{1}$ \\ ${ }^{1}$ Department of Nutrition Science and Feed Technology, Faculty of Animal Husbandry, Universitas Andalas. Jl. Raya Unand, Limau Manis, Padang \\ 25163, West Sumatra, Indonesia. Tel./fax.: +62-751-71464, `email: novirman55@gmail.com, •v ronipazla@ansci.unand.ac.id \\ ${ }^{2}$ Department of Education Quality Assurance, Faculty of Medical, Universitas Baiturrahmah. Jalan Raya By Pass Km. 14, Aie Pacah, Padang 25586, \\ West Sumatra, Indonesia \\ ${ }^{3}$ Department of Extension Science and Development Communication, Graduate Program, Universitas Andalas. Jl. Raya Unand, Limau Manis, Padang \\ 25163, West Sumatra, Indonesia. \\ ${ }^{4}$ Department of Nutrition Science and Feed Technology, Faculty of Animal Husbandry, Institut Pertanian Bogor. Jl. Agatis, Kampus IPB Darmaga, \\ Bogor 16680, West Java, Indonesia
}

Manuscript received: 16 September 2020. Revision accepted: 16 October 2020.

\begin{abstract}
Jamarun N, Pazla R, Arief, Jayanegara A, Yanti G. 2020. Chemical composition and rumen fermentation profile of mangrove leaves (Avicennia marina) from West Sumatra, Indonesia. Biodiversitas 21: 5230-5236. This study aimed to determine the potential of mangrove leaves of Avicennia marina for ruminant animal feed. Laboratory tests were carried out on A. marina with three replicates. Parameters measured were proximate and fiber contents, rumen fluid profile ( $\mathrm{pH}, \mathrm{NH}_{3}$ and VFA), digestibility of nutrients (DM, Ash, $\mathrm{CP}, \mathrm{CF}, \mathrm{NDF}, \mathrm{ADF}$, cellulose, and hemicellulose), macro and micro mineral contents, and phytochemical compounds. The results showed the nutritional content of A. marina were CP 13.37\%; Ash 7.17\%; lignin 7.34\%; TDN 79\%, rumen fluid profile is in reasonable condition, digestibility of food substances is more than $50 \%$, rich in macro and micro minerals and contains phytochemical compounds such as phenols, steroids, triterpenoids, and tannins. Macro and micro minerals content of $\mathrm{Ca} 0.38 \%, \mathrm{Na} 0.20 \%, \mathrm{Mg} 0.20 \%, \mathrm{~K} 0.48 \%, \mathrm{P}$ $0.51 \%, \mathrm{~S} 0.01 \%, \mathrm{Cl} 1.03 \%, \mathrm{Fe} 388 \mathrm{ppm}, \mathrm{Zn} 164 \mathrm{ppm}, \mathrm{Mn} 211 \mathrm{ppm}$, and $\mathrm{Cu} 128 \mathrm{ppm}$. This research concludes that A. marina is very potential to be used as a ruminant animal feed.
\end{abstract}

Keywords: Avicennia marina, mangroves, minerals, phytochemicals, proximate, rumen fluid

\section{INTRODUCTION}

Indonesia is a country with the most extensive mangrove forests globally (Richards and Friess 2016; Bunting et al. 2018). Indonesia's reliable mangrove forests are currently 3,361,216.61 ha (Rahardian et al. 2019). Mangrove forests help to reduce the impact of hurricanes, large waves, and winds from tropical cyclones. Mangrove trees reduce wave energy as they pass through mangrove forests and become barriers between streams and land (United Nations Environment Program 2014). When the sea is high tide, mangrove forests are flooded with water, and at low tide, thick mud covers the surface of the soil, which stores wealthy organic material (FAO 2007).

Avicennia marina (Forsk.) Vierh.) is a mangrove tree species almost always found in major mangrove ecosystems (Tomlinson 1986). Local people use this plant's stems and twigs for firewood, furniture, building materials, boat balancing joints, and fishing net dyes (Armitage 2002). These products are harvested on a small and large scale, contributing to local livelihoods and national exports.

Avicennia marina leaves have a pointed shape at the tip and are green at the front and grayish at the bottom with about $5-11 \mathrm{~cm}$. The flowers are small round with a diameter of about $0.4-0.5 \mathrm{~cm}$ and yellow to orange, while the fruit is round with a pointed tip and smooth-haired surface, green with a length of $1.5-2.5 \mathrm{~cm}$ and a width of
1.5-2.0 $\mathrm{cm}$ (Kitamura et al. 1997). In the coastal areas of Indonesia, people use their leaves to feed goats. These leaves fall off, and the amount is quite adequate as a forage source for animal feed. Nevertheless, to date, there is little research that explores the potential of $A$. marina leaves as ruminant feed. This study aimed to evaluate $A$. marina leaves' possibility as ruminant feed in terms of nutritional content, phytochemicals, digestibility, and rumen fluid profile in vitro. This research held on Sebelas Tarusan Subdistrict, Pesisir Selatan District, Province of West Sumatra, Indonesia. The mangrove area mostly consists of $A$. marina, but there are also Avicennia alba plant clusters in some locations.

\section{MATERIALS AND METHODS}

\section{Sample collection and nutrient analysis}

The materials used in this experiment consist of Avicennia marina leaves and fruit, Tithonia diversifolia leaves, Gliricidia sepium leaves, Leucaena leucocephala fruit, and leaves. A. marina leaves were taken from the South Coast mangrove forest, Sebelas Tarusan Sub-district, Pesisir Selatan District, West Sumatra, Indonesia. T. diversifolia, G. sepium, and L. leucocephala leaves were collected from the experimental gardens of the Faculty of Agriculture, Andalas University, Padang, Indonesia. 
Leaves from these species have been traditionally used for feeding ruminants and therefore used as references for evaluating A. marina leaves' potency.

Avicennia marina leaf samples taken were the top 3-5 leaves, such as tea leaves. The samples taken were dried at $60{ }^{\circ} \mathrm{C}$ for 24 hours. The sample is grinded until smooth. All the leaf samples were oven-dried at $60^{\circ} \mathrm{C}$ for $24 \mathrm{~h}$. Especially for A. marina leaves, the chemical composition, rumen fluid profile, and nutrient digestibility were tested. Proximate content was analyzed by standard methods, according to AOAC (2000). Neutral detergent fiber (NDF), cellulose, and acid detergent fiber (ADF) were analyzed according to Van Soest et al. (1991). In-vitro rumen incubation method followed the procedure of Tilley and Terry (1963), macro and micro minerals using Inductively Coupled Plasma Optical Emission Spectroscopy (ICPOES) while phytochemical compounds by the Harborne (1998). All the analyses were carried out at the Biochemistry Laboratory of the Faculty of Pharmacy and Water Laboratory of the Faculty of Engineering, Andalas University, Padang, Indonesia. All the data obtained were described descriptively.

\section{Phytochemical analysis}

Phytochemical analysis was carried out by the extraction method based on Franswort (1996). Before phytochemical analysis, A. marina fruit and leaves, $T$. diversifolia leaves, G. sepium leaves, L. leucocephala fruit, and leaves were ground into flour, put into a bottle, added with $90 \%$ methanol solvent in a ratio of $1: 3(\mathrm{w} / \mathrm{v})$, macerated with solvent methanol $3 \times 24$ hours and every 24 hours the methanol solvent was replaced. The maceration results were then filtered using Whatman filter paper no. 42 so that the resulting filtrate. The filtrate was subjected to several phytochemical screening tests, i.e., alkaloid, flavonoid, phenolic, saponin, steroid, and triterpenoid tests. For the alkaloid test, the chloroform layer was added ten drops of $\mathrm{H}_{2} \mathrm{SO}_{4}$ and shaken slowly, allowed to form an acidic layer. A layer of acid (the part under the clear ring formed from the addition of $\mathrm{H}_{2} \mathrm{SO}_{4}$ ) was taken, and one drop of Meyer reagent was added. A white mist characterized positive reactions. The flavonoid Test layer of water as much as $2 \mathrm{ml}$ from the preparation stage was taken and put into a test tube. Then 1-2 grains of Magnesium was added, and three drops of $\mathrm{HCl}$ were added. Positive samples contain flavonoids. If they form orange to Concerning the phenolic test, a layer of water from the preparation stage was taken and put into a drip plate, then added ferric chloride to each drip plate that has been sampled. The formation of blue and purple characterizes the presence of phenolic compounds. A $2 \mathrm{ml}$ layer of water from the preparation stage was taken and put into a test tube then shaken for the saponin test. Positive samples contain saponins if they are formed permanently, which do not disappear within 15 minutes. Steroid and triterpenoid test was performed by taking the chloroform layer from the preparation stage and put into a Pasteur pipette, which contains charcoal. The filtrate that comes out of Pasteur's pipette was inserted into three holes on the drip plate, adding one drop of anhydrous acetic acid and one drop of $\mathrm{H}_{2} \mathrm{SO}_{4}$. Positive samples containing steroid compounds were shown in blue to purple, while positive samples contain triterpenoid compounds if produced in red.

\section{Determination of mineral contents}

Avicennia marina leaves and fruits, $T$. diversifolia leaves, G. sepium leaves, L. leucocephala fruits and leaves were dried in an oven at $60^{\circ} \mathrm{C}$ for 24 hours. Then the sample was ground and filtered using a 20 mesh filter to obtain a powdered sample. One gram of powdered sample was added with $2 \mathrm{ml}$ of distilled water, then dried in the furnace at $150{ }^{\circ} \mathrm{C}$ for 15 minutes. Then the sample was cooled at room temperature. Dilute using aqua dest to a volume of $25 \mathrm{ml}$, and then the sample was filtered using 45 mesh filter paper. The destruction results were analyzed in the mineral content of $\mathrm{Fe}, \mathrm{Zn}, \mathrm{Mn}, \mathrm{Cu}$, and $\mathrm{Co}$ using the Inductively Coupled Plasma Optical Emission Spectroscopy (ICP-OES) tool.
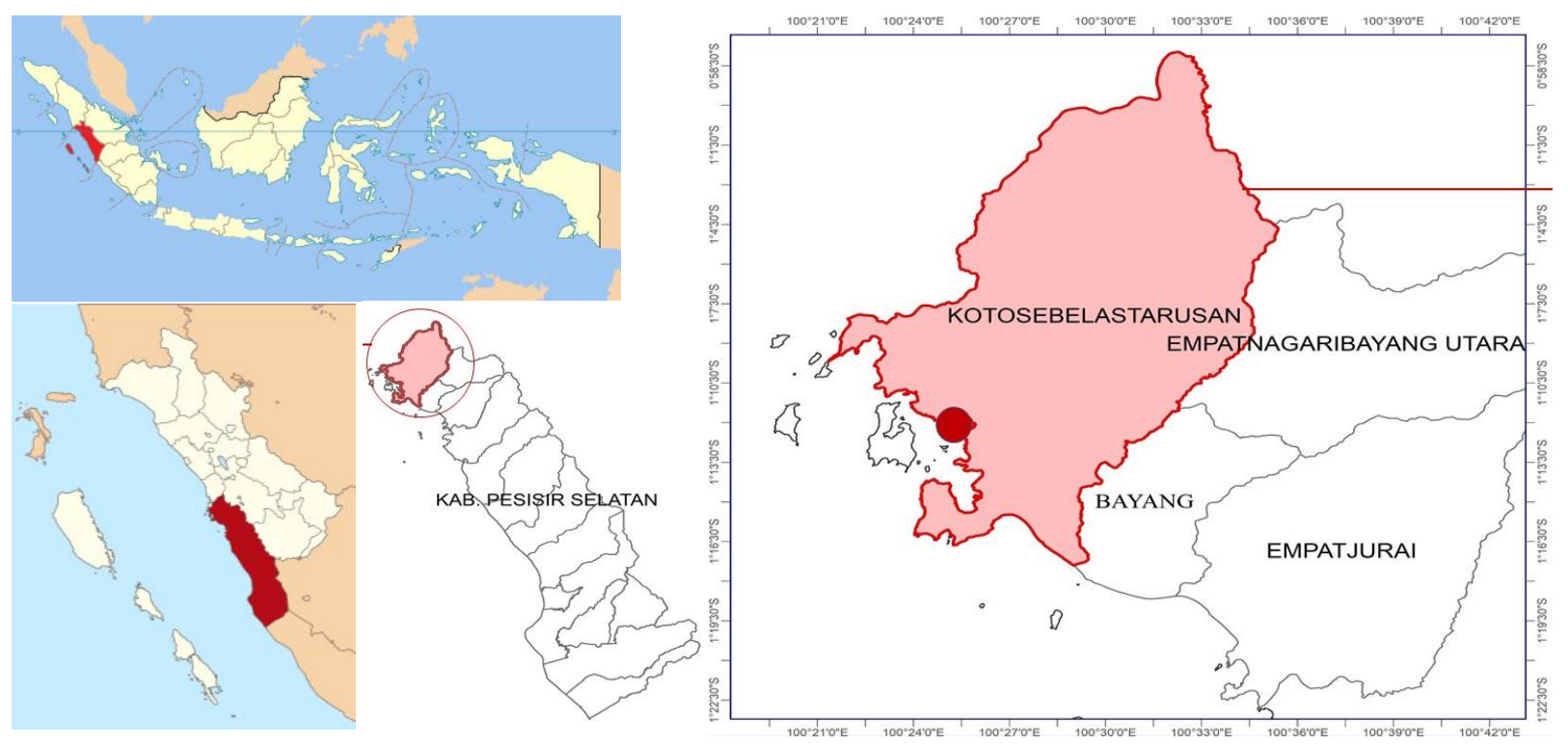

Figure 1. Location of Avicennia marina leaf sampling in Sebelas Tarusan Sub-district, Pesisir Selatan District, West Sumatra, Indonesia 


\section{RESULT AND DISCUSSION}

\section{Chemical composition of Avicennia marina leaves}

Avicennia marina leaves contain $13.37 \%$ crude protein (CP) with 79\% Total Digestible Nutrient (TDN) (Table 1). This value makes A. marina leaves included in the category of high-quality forage. (Jamarun and Zain 2013) classify forage quality in three categories based on $\mathrm{CP}$ and TDN content, namely low quality forage (CP $<4 \%$, TDN $>40 \%$ ), medium quality forage (CP 5-10\%, TDN $40-50 \%$ ) and high-quality forage (CP> $10 \%$, TDN $>50 \%)$. High forage $\mathrm{CP}$ and TDN are needed by livestock to optimize their growth and production. Some CP in the rumen will be overhauled into $\mathrm{NH}_{3}$ by proteolytic enzymes produced by rumen microbes. $\mathrm{NH}_{3}$ concentration is an important source of $\mathrm{N}$ for rumen microbes and is used for microbial protein synthesis. $\mathrm{NH}_{3}$ production is influenced by the amount of protein in feed ingredients (Pazla et al. 2018a). High TDN illustrates that these leaves have a high digestibility, so only a few nutrients come out as feces.

The high CP content in A. marina leaves is caused by soil organic matter (OM). (FAO 2007) In mangrove areas, there is high organic matter in thick mud that lines the surface of the land at low tide. Land influences nutrition, plant growth, and development. Plants will grow and develop optimally if the soil conditions in which they live fit the nutritional and nutrient requirements. According to Kennish (2000), mangrove roots can accumulate sediment and play a role in forming soil formations. Mangroves are suppliers of organic material to provide food for organisms that live in the surrounding waters. Sedimentation that occurs in mangrove areas is different from other regions. Sources of sedimentation come from the land, sea, and mangrove areas in the form of deposited leaf deposits, twigs, and dead organisms that are collected so that this region is rich in organic and mineral materials such as $\mathrm{N}, \mathrm{P}$, $\mathrm{K}, \mathrm{Fe}$, and $\mathrm{Mg}$ (Nugroho et al. 2013). A. marina leaves' crude protein value in this study was higher than reported by (Handayani 2013), 11.04\%, and lower than (Ghosh et al. $2015), 15.14 \%$. This variation in crude protein values can be caused by plant age, soil fertility, and the source (Jama et al. 2000).

The high protein content of a feed ingredient will also increase the value of organic matter. This is due to crude protein is part of organic material. Table 1 shows the organic matter content of the leaves is also relatively high, at $92.83 \%$. High organic matter will automatically reduce the value of ash content. The higher the ash content, the worse the quality of feed ingredients (Suparjo 2010). (SNI 2017) suggests that cattle's low ash content is $12 \%$ maximum, while poultry livestock is $8 \%$. The low-crude fat (CF) content in these leaves (3.18\%) is advantageous in ruminant animals. The high-fat content in feed ingredients has been reported to be a cause of digestive and metabolic disorders in cattle (Atteh 2002). Preston and Leng (1987) supported this, and Palmquist and Jenkins (1980) stated that ruminant animal feed ingredients' standard fat content is below $5 \%$.
Crude fiber is needed for ruminants to maintain the development of rumen microbes. Crude fiber that is too low will interfere with the digestive system of ruminants. The A. marina crude fiber content (12.18\%) is almost equal to the minimum requirement of crude fiber content in feed ingredients, which is $13 \%$ for cattle, according to Sudarmono and Sugeng (2008).

The NDF content is closely related to feeding consumption because all its components meet the rumen space and are slow to digest. The lower the NDF content, the more food can be consumed. ADF's content (cellulose, lignin, silica) is an indicator of forage digestibility because lignin's content is part of an indigestible fraction (Pazla et al. 2020). NDF is always higher than ADF because ADF does not contain hemicellulose. NRC (2001) suggests a minimum of NDF in feed $21 \%$ with ADF $19 \%$. The percentage of ADF and NDF content given to livestock should be $25-45 \%$ ADF and 30-60\% NDF from forage dry matter (Anas 2010). The average value of lignin that livestock can tolerate is 7\% (Goering and Van Soest 1970). The NDF, ADF, and lignin values of these leaves are still within the tolerance range for ruminant animal feed.

Table 1. Chemical composition of Avicennia marina leaves

\begin{tabular}{lc} 
Chemical composition & $\%$ \\
\hline Dry matter & $89.19 \pm 0.07$ \\
Ash & $7.17 \pm 0.09$ \\
Organic matter & $92.83 \pm 0.11$ \\
Crude protein & $13.37 \pm 0.23$ \\
Crude fiber & $12.18 \pm 0.27$ \\
Crude fat & $3.18 \pm 0.39$ \\
NDF & $45.99 \pm 0.41$ \\
ADF & $35.95 \pm 0.43$ \\
Cellulose & $23.10 \pm 0.42$ \\
Hemicellulose & $10.03 \pm 0.67$ \\
Lignin & $7.34 \pm 0.72$ \\
TDN & $79.00 \pm 0.98$ \\
\hline
\end{tabular}

Table 2. Rumen fluid profile and nutrition in vitro digestibility from Avicennia marina leaves

\begin{tabular}{lc}
\hline Parameters & Value \\
\hline Rumen fluid profile & $6.79 \pm 0.02$ \\
$\mathrm{pH}$ & $117.5 \pm 0.04$ \\
$\mathrm{VFA}(\mathrm{mM})$ & $16.88 \pm 0.51$ \\
$\mathrm{NH}_{3}(\mathrm{mM})$ & \\
Nutrition digestibility $(\%)$ & $56.68 \pm 0.54$ \\
$\mathrm{DM}$ & $63.74 \pm 0.67$ \\
$\mathrm{OM}$ & $69.96 \pm 0.62$ \\
$\mathrm{CP}$ & $61.37 \pm 1.58$ \\
$\mathrm{CF}$ & $57.44 \pm 0.96$ \\
$\mathrm{NDF}$ & $51.44 \pm 0.92$ \\
$\mathrm{ADF}$ & $60.24 \pm 0.73$ \\
Cellulose & $62.03 \pm 1.04$ \\
Hemicellulose &
\end{tabular}


Table 3. Mineral macrocontent of Avicennia marina, Thitonia diversifolia, Gliricidia sepium and Leucaena leucocephala

\begin{tabular}{lcccccc}
\hline Mineral & \multicolumn{2}{c}{ Avicennia marina } & Thitonia diversifolia & Gliricidia sepium & \multicolumn{2}{c}{ Leucaena leucocephala } \\
\cline { 2 - 7 } content $(\%)$ & Leaf & Fruit & Leaf & Leaf & Leaf & Fruit \\
\hline $\mathrm{Ca}$ & $0.38 \pm 0.007$ & $0.35 \pm 0.014$ & $0.21 \pm 0.007$ & $0.25 \pm 0.014$ & $0.28 \pm 0.014$ & $0.24 \pm 0.007$ \\
$\mathrm{Na}$ & $0.20 \pm 0.014$ & $0.17 \pm 0.007$ & $0.09 \pm 0$ & $0.14 \pm 0.014$ & $0.16 \pm 0.007$ & $0.13 \pm 0$ \\
$\mathrm{Mg}$ & $0.20 \pm 0.07$ & $0.19 \pm 0.007$ & $0.20 \pm 0.007$ & $0.13 \pm 0.007$ & $0.16 \pm 0.007$ & $0.15 \pm 0.007$ \\
$\mathrm{~K}$ & $0.48 \pm 0.021$ & $0.41 \pm 0.014$ & $0.26 \pm 0.007$ & $0.28 \pm 0.014$ & $0.32 \pm 0.014$ & $0.27 \pm 0.014$ \\
$\mathrm{P}$ & $0.51 \pm 0.014$ & $0.47 \pm 0.014$ & $0.32 \pm 0.014$ & $0.23 \pm 0.007$ & $0.42 \pm 0.014$ & $0.23 \pm 0.014$ \\
$\mathrm{~S}$ & $0.01 \pm 0$ & $0.0092 \pm<0.001$ & $0.0052 \pm<0.001$ & $0.0063 \pm 0$ & $0.0071 \pm<0.001$ & $0.0054 \pm<0.001$ \\
$\mathrm{Cl}$ & $1.03 \pm 0.021$ & $0.99 \pm 0$ & $0.89 \pm 0.014$ & $0.92 \pm 0.021$ & $0.96 \pm 0.014$ & $0.85 \pm 0.021$ \\
\hline
\end{tabular}

Table 4. Mineral microcontent of Avicennia marina, Thitonia diversifolia, Gliricidia sepium and Leucaena leucocephala

\begin{tabular}{|c|c|c|c|c|c|c|}
\hline \multirow{2}{*}{$\begin{array}{l}\text { Mineral content } \\
\text { (ppm) }\end{array}$} & \multicolumn{2}{|c|}{ Avicennia marina } & \multirow{2}{*}{$\begin{array}{c}\text { Thitonia diversifolia } \\
\text { Leaf }\end{array}$} & \multirow{2}{*}{$\begin{array}{c}\text { Gliricidia sepium } \\
\text { Leaf }\end{array}$} & \multicolumn{2}{|c|}{ Leucaena leucocephala } \\
\hline & Leaf & Fruit & & & Leaf & Fruit \\
\hline $\mathrm{Fe}$ & $388 \pm<0.001$ & $293 \pm<0.001$ & $293 \pm<0.001$ & $228 \pm<0.001$ & $390 \pm<0.001$ & $328 \pm<0.001$ \\
\hline $\mathrm{Zn}$ & $164 \pm<0.001$ & $135 \pm<0.001$ & $76 \pm<0.001$ & $56 \pm<0.001$ & $88 \pm<0.001$ & $75 \pm<0.001$ \\
\hline $\mathrm{Mn}$ & $211 \pm<0.001$ & $139 \pm<0.001$ & $75 \pm<0.001$ & $56 \pm<0.001$ & $88 \pm<0.001$ & $75 \pm<0.001$ \\
\hline $\mathrm{Cu}$ & $128 \pm<0.001$ & $107 \pm<0.001$ & $40 \pm<0.001$ & $43 \pm<0.001$ & $83 \pm<0.001$ & $53 \pm<0.001$ \\
\hline
\end{tabular}

Table 5. Phytochemical composition test results of Avicennia marina, Tithonia diversifolia, Gliricidia sepium dan Leucaena leucocephala

\begin{tabular}{lcccccc}
\hline Parameters & \multicolumn{7}{c}{ Test result } \\
\cline { 2 - 7 } & $\begin{array}{c}\text { Avicennia } \\
\text { marina fruit }\end{array}$ & $\begin{array}{c}\text { Avicennia } \\
\text { marina leaves }\end{array}$ & $\begin{array}{c}\text { Tithonia } \\
\text { diversifolia leaves }\end{array}$ & $\begin{array}{c}\text { Gliricidia } \\
\text { sepium leaves }\end{array}$ & $\begin{array}{c}\text { Leucaena } \\
\text { leucocephala } \\
\text { leaves }\end{array}$ & $\begin{array}{c}\text { Leucaena } \\
\text { leucocephala } \\
\text { fruit }\end{array}$ \\
\hline Alkaloid & + & - & - & - & - & - \\
Flavonoid & - & - & - & - & - & - \\
Phenols & + & + & - & - & - & - \\
Saponin & - & - & + & + & + & + \\
Steroid & + & + & + & + & + & + \\
Triterpenoid & + & + & + & + & + \\
Tanin & + & + & & & + & + \\
\hline
\end{tabular}

\section{Rumen fluid profile and nutrition digestibility}

The $\mathrm{pH}$ value of the rumen fluid from A. marina leaves in this study was within the normal range for the growth and development of rumen microbes, mostly bacteria (Table 2). The ideal $\mathrm{pH}$ for fiber digestion is 6.4-6.8 (France and Siddon 1993). The pH below 6.2 will reduce plant fiber digestibility because cellulolytic bacteria's activity is inhibited (Erdman 1988). A pH value above 7.1 can reduce the microbial population drastically so that the energy generated from the rumen fermentation process is low (Van Soest 1982).

Volatile fatty acid (VFA) is a source of energy for the growth and development of rumen microbes. The VFA value produced by $A$. marina leaves sufficient for rumen microbes to grow and develop optimally. Mc Donald et al. (2010) stated that the optimum VFA condition is 80-160 mM. The high value of the resulting VFA indicates that $A$. marina leaves are a feed material with a high level of fermentability, which is suitable as a source of forage for ruminants. The low lignin content will make it easier for enzymes from rumen microbes to penetrate cellulose and hemicellulose, which are the main components of forming VFA. The high protein content of A. marina leaves also contributed to the high VFA value. There is a positive correlation between high crude protein values and VFA values (Jamarun et al. 2017b; Jamarun et al. 2018).

The concentration of $\mathrm{NH}_{3}$ in A. marina leaves in this study was included in the amount of $\mathrm{NH}_{3}$ that supports rumen microbial growth, namely $6 \mathrm{mM}-21 \mathrm{mM}$ (Mc Donald 2010). Paengkoum et al. (2006) stated that the maximum $\mathrm{NH}_{3}$ concentration required for rumen microbes to digest feed was 3.57-14.28 mM. Rumen microbes use $\mathrm{NH}_{3}$ as a $\mathrm{N}$ for microbial protein synthesis source, and its value is also influenced by crude protein levels (Pazla et al. 2018a). The $\mathrm{pH}, \mathrm{VFA}$, and $\mathrm{NH}_{3}$ values of $A$. marina leaves in this study were almost the same as other forages such as T. diversifolia $(6.78,125.88 \mathrm{mM}, 22.48 \mathrm{mM})$ and Elephant grass (6.79, $87.53 \mathrm{mM} 20,41 \mathrm{mM})$ (Jamarun et al. 2019).

Feed digestibility is a large amount of feed that livestock can utilize to meet basic needs and production. Based on Table 2 above, it can be seen that rumen microbes can digest more than $50 \%$ of the nutrients from 
these leaves; this is due to the low lignin content. Lignin in feed ingredients can reduce digestibility, as reported by Jamarun et al. (2017a). Rumen microbes can digest food substances in feed ingredients when the lignin content is low. Imsya et al. (2013) stated that lignin in plant cell walls limits the feed material's digestibility. Crude protein content in feed ingredients will also affect the digestibility level of a feed ingredient. The high protein content of $A$. marina leaves will provide more nitrogen for the growth of rumen microbes. Profitable microbial growth will lead to better feed digestibility (Febrina et al. 2016).

\section{Macro and micro mineral contents}

The amount of macro minerals $(\mathrm{Ca}, \mathrm{Na}, \mathrm{Mg}, \mathrm{K}, \mathrm{S}, \mathrm{P}$, and $\mathrm{Cl}$ ) A. marina leaves is higher than that of A. marina fruit, T. diversifolia, G. sepium leaves, and L. leucocephala leaves (Table 3 ). The high mineral content is because the soil in the mangrove forest is rich in minerals and organic matter. Nugroho et al. (2013) explained that the sedimentation in the mangrove area is different from other depositional environments. Sources of sediment in mangrove areas come from land and sea (allochthonous) and from the mangrove area itself (autochtonous) in the form of heaps of fallen leaves, twigs, and dead organisms deposited in the mangrove area and contain a lot of organic and mineral matter ( $\mathrm{N}, \mathrm{P}, \mathrm{K}, \mathrm{Fe}$, and $\mathrm{Mg}$ ). The allochthonous sediment is deposited in mangroves through sediment transport, where suspended particles are carried by tidal currents stored in the mangrove area. Because mangroves have a unique root system, they can reduce tidal currents in the mangrove area.

Macrominerals are needed by livestock to build body structures such as bones and teeth (Jamarun and Zain 2013). $P$ mineral is an important mineral to support the growth of rumen microbes digesting fiber (Suyitman et al. 2020). Sulfur minerals are needed by rumen microbes to form amino acids that contain sulfur (Bal and Ozturk 2006). Mineral $P$ and $S$ can stimulate rumen microbial performance to improve feed digestibility (Pazla et al. 2018b). Mineral P, S, and Mg were able to increase rumen VFA concentrations (Febrina et al. 2016). Minerals Ca, P, and $\mathrm{Mg}$ at normal levels in the rumen can increase rumen microbial activity in digesting cellulose and VFA (Adriani and Mushawwir 2009). Na functions to increase appetite and maintain osmotic pressure (Jamarun and Zain 2013). A. marina leaves' mineral content is still in the normal range to help supply the mineral needs. According to Mc Dowell et al. (1983) the range of normal values for mineral content in animal feed for $\mathrm{Ca}$ is $0.17-1.53 \%, \mathrm{Mg} 0.05-0.25 \%, \mathrm{P}$ $0.17-0.59 \%$, K $0.50-0.70 \%$, Na $0.01-0.06 \%$, S $0.08-0.15 \%$.

Fe's mineral content in $A$. marina leaves relatively high compared to A. marina fruit, T. diversifolia, G. sepium, and L. leucocephala fruit, but $L$. leucocephala leaves have slightly higher Fe (Table 4). Nugroho (2008) states that Fe content in grass is usually $100-200$ ppm while in legume 200-300 ppm. According to Darmono (2007), mineral Fe is used in the enzymatic metabolism of hemoglobin in the livestock body.

The minerals $\mathrm{Zn}, \mathrm{Mn}$, and $\mathrm{Cu}$ in A. marina leaves show the highest value than other forages in Table 3 . Nugroho
(2008) states that Mn functions as carbohydrate synthesis, mucopolysaccharide, and enzyme systems, such as pyruvate carboxylase and arginine synthetase. In addition to enzymatic reactions, $\mathrm{Mn}$ also functions for growth and reproduction of livestock, Onwuka et al. (2001) which states that Mn's mineral content in goats ranges from 2.98$13.9 \mathrm{mg} / \mathrm{dl}$. Based on these data, it can be concluded that the livestock reared with A. marina leaf-based feed does not experience $\mathrm{Mn}$ mineral deficiency because the $\mathrm{Mn}$ content in the forage is sufficient. Nugroho's (2008) opinion states that $\mathrm{Mn}$ mineral deficiency rarely occurs because Mn levels in the feed are enough for livestock needs.

Zinc $(\mathrm{Zn})$ is the micro-mineral often deficient for rumen microbial growth (Leng 1991). To maximize feed degradation in the rumen, the adequacy of $\mathrm{Zn}$ minerals is critical, given the strategic role of $\mathrm{Zn}$ in increasing rumen microbial growth and as an activator of many enzymes (Elihasridas et al. 2012). Mineral Zn can stimulate rumen microbial growth and improve the appearance of livestock. The $\mathrm{Zn}$ content in Indonesia's ruminant animal feed ranges from $20-38 \mathrm{mg} / \mathrm{kg}$ of dry ration material (Little 1986). This value is far below the need for rumen microbes, namely $130-220 \mathrm{mg} / \mathrm{kg}$ of dry ration material (Hungate 1966). Zn deficiency can interfere with rumen microbial metabolism and decrease enzyme activity. Therefore to achieve high feed degradation and microbial growth in the rumen, Zn must be available in sufficient and balanced amounts. The amount of $\mathrm{Zn}$ in A. marina leaves still in the range to meet the needs of rumen microbes.

According to Darmono and Bahri (1989), the low $\mathrm{Cu}$ in animal feed sources will adversely affect Fe intake, even though the $\mathrm{Fe}$ content in the feed is adequate. It was reported that low $\mathrm{Cu}$ content in forage is one of the causes of anemia in livestock. According to Little (1986), several types of grass or forage are used as sources of feed for ruminants in Indonesia, especially on Sumatra, whose Cunya content is below average (low) limits. As reported by Prabowo et al. (1997) and Mathius (1988) from the results of field examinations that are commonly used as the main feed for goats generally have $\mathrm{Cu}$ content below the standard (critical) limit. The $\mathrm{Cu}$ content will be even lower during the dry season. This results in animals that consume them, thus experiencing mineral deficiencies. Mc Dowell et al. (1992) states that $\mathrm{Cu}$ requirements are influenced by the levels of other mineral rations, which increases the need for ruminants in the presence of high molybdenum (Mo) levels. NRC (1989) recommends a $\mathrm{Cu}$ requirement figure of $10 \mathrm{mg} / \mathrm{kg}$ for ruminants. The mineral value of $\mathrm{Cu}$ in the leaves of the A. marina is sufficient for livestock needs. The definition of $\mathrm{Cu}$ will cause bone disorders (paralysis), joint swelling, bone fragility. Pigment deficiency in $\mathrm{Cu}-$ deficient animals and humans. However, giving enough copper salt, especially to sheep, will cause accumulation in the liver. Sheep are sensitive to $20-30 \mathrm{mg} \mathrm{Cu} / \mathrm{kg}$ of $\mathrm{Cu}$ ration (Tillman et al. 1998).

\section{Phytochemical contents}

The phytochemical contents of the samples were varied (Table 5). Ruminant animals are more resistant to feed 
ingredients that contain phytochemicals than poultry. This is due to some phytochemicals that can be used to simplify the process of feed metabolism. Tannins are phytochemicals that function as by-pass protein agents. This means that the protein from feed ingredients eaten by livestock will be protected from rumen bacteria's degradation to enter the small intestine. This tannin can only release its bonds with feed ingredients by enzymes in the small intestine and low $\mathrm{pH}$ levels, while in the rumen, tannins are problematic in the rumen bacterial break and normal rumen pH (Jamarun and Zain 2013). Tannin addition increased neutral detergent insoluble crude protein (NDICP) and acid detergent insoluble CP (ADICP) (Jayanegara et al. 2019). However, the levels should not be excessive because if excessive phytochemicals can hurt livestock productivity. Phytochemicals in feed ingredients such as T. diversifolia, G. sepium, and L. leucocephala have been tested in livestock, apparently still in normal conditions for consumption by ruminant animals and do not show a negative effect on livestock metabolic activities (Arief et al. 2020; Pazla 2018; Ningrat et al. 2018). Jamarun et al. (2019) tested T. diversifolia by using up to a $100 \%$ level, still having a positive effect on the digestibility of dry matter and organic matter and the fermentability of rumen fluids such as $\mathrm{pH}, \mathrm{NH}_{3}$, and VFA, even better when compared to elephant grass. Fasuyi et al. (2010) identified many phytochemicals found in $T$. diversifolia such as phytates, alkaloids, saponins, and far more than A. marina leaves. This study confirms that A. marina leaves are entirely safe for livestock consumption. In conclusion, the research showed that $A$. marina leaves could be used as alternative feed ingredients for ruminant animals with CP content of $13.37 \%$, lignin $7.34 \%$, rich in macro and micro minerals, and containing phytochemical compounds such as tannins, steroids, and triterpenoids.

\section{ACKNOWLEDGEMENTS}

Andalas University funded this research by the research contract No: T/12/UN.16.17/PP.KP-KPR1GB/LPPM/2019 the Fiscal Year 2019.

\section{REFERENCES}

Adriani L, Mushawwir A. 2009. Level of blood glucose, lactose, and dairy cattle milk yield at a different level of macromineral supplementation. J Indon Trop Anim Agric 34 (2): 88-95.

AOAC. 2000. Official methods of analysis. Association of analytical chemists, Arlington, Virginia, USA.

Anas S. 2010. Kandungan NDF dan ADF silase campuran jerami jagung (I) dengan beberapa level daun gamal (Gliricidia maculata). Balai Pengkajian Teknologi Pertanian (BPTP), Gorontalo. [Indonesian]

Arief, Sowmen S, Rusdimansyah, Pazla R, Rizqan. 2020. Milk production and quality of Etawa crossbreed dairy goat given Tithonia diversifolia, corn waste, and concentrate based palm kernel cake. Biodiversitas 21 (9): 4004-4009.

Armitage D. 2002. Socio-institutional dynamics and the political ecology of mangrove observation Indonesia. Glob Environ Change 12: 203 217.

Atteh JO. 2002. Principles and practice of livestock feed manufacturing. Adlek Printers, Ilorin, Niger.
Bal MA, Ozturk D. 2006. Effects of sulfur-containing supplements on ruminal fermentation and microbial protein synthesis. Res J Anim Vet Sci 1: 33-36.

Bunting P, Ake R, Richard M, Lucas, Lisa MR, Lammert H, Nathan T, Andy H, Takuya I, Masanobu Sand C, Max F . 2018. The global mangrove watch-a new 2010 global baseline of mangrove extent. Remote Sens 10 (10): 1669.

Darmono, Bahri S. 1989. Defisiensi tembaga dan seng pada sapi di daerah Kalimantan Selatan. Penyakit Hewan 21 (38): 128-131. [Indonesian]

Darmono. 2007. Penyakit defiseinsi mineral pada ternak ruminansia dan upaya pencegahannya. Jurnal Litbang Pertanian 26 (3): 104-108. [Indonesian]

Elihasridas. 2012. Respon suplementasi mineral zink (zn) terhadap kecernaan in-vitro ransum tongkol jagung amoniasi. Jurnal Peternakan 9 (2): 9-14. [Indonesian]

Erdman RA. 1988. Dietary buffering requirements of lactating dairy cows. A Review. J Dairy Sci 71: 3246-3246.

FAO. 2007. The World's mangroves 1980-2005. Food and Agriculture Organization of the United Nations, Rome.

Fasuyi AO, Dairo FAS, Ibitayo FJ. 2010. Ensiling wild sunflower (Tithonia diversifolia) leaves with sugar cane molasses. Livest Res Rural Dev 22 (3): 42.

Febrina D, Jamarun N, Zain M, Khasrad. 2016. The Effects of P, S and $\mathrm{Mg}$ supplementation of oil palm fronds fermented by Phanerochayte chrysosporium on rumen fluid characteristics and microbial protein synthesis. Pak J Nutr 15 (3): 299-304.

France J, Siddons RC. 1993. Volatile fatty acids production. In: Forbes JM, France J (eds.). Quantitative Aspect of Ruminant Digestion and Metabolism. CAB Internasional, Wallingford, UK.

Franswort NR. 1996. Biological and phytochemical screenings of plant. J Pharm Sci 55: 225-265.

Ghosh S, Somraj C, Agniv N. 2015. Proximate composition of some mangrove leaves used As alternative fodders in Indian Sunderban Region. Intl J Livest Res 5 (11): 62-65.

Goering HK, Van Soest PJ. 1970. Forage fiber analysis. USDA Agric. Handbook No. 379. USDA-ARS, Washington, DC.

Handayani S. 2013. Kandungan flavonoid kulit batang dan daun pohon api-api (Avicennia marina (forks.)vierh.) sebagai senyawa aktif antioksidan. [Thesis]. Bogor Agricultural University, Bogor. [Indonesian]

Harborne AJ. 1998. Phytochemical Methods: A Guide to Modern Techniques of Plant Analysis. Springer, Nederland.

Hungate RR. 1998. The rumen and its microbe. Department of Bacteriology and Agriculture Experiment Station University of California. Davis California Academy Press, London.

Imsya A, Laconi EB, Wiryawan KG, Widyastuti Y. 2013. In Vitro digestibility of ration containing different levels of palm oil frond fermented with Phanerochaete chrysosporium. Media Peternakan 36 (2): 131-136. [Indonesian]

Jama B, Palm CA, Buresh RJ. 2000. Tithonia diversifolia as a green manure for soil fertility improvement in western Kenya: A review. Agrofor Syst 49: 201-221.

Jamarun N, Zain M. 2013. Dasar nutrisi ruminansia. Jasa Surya Press, Padang. [Indonesian]

Jamarun N, Zain M, Arief, Pazla R. 2017a. Effects of calcium, phosphorus and manganese supplementation during oil palm frond fermentation by Phanerochaete chrysosporium on laccase activity and in vitro digestibility. Pak J Nutr 16 (3): 119-124.

Jamarun N, Zain M, Arief, Pazla R. 2017b. Effects of calcium (Ca), phosphorus (p) and manganese (mn) supplementation during oil palm frond fermentation by Phanerochaete chrysosporium on rumen fluid characteristics and microbial protein synthesis. Pak J Nutr 16 (6): 393-399.

Jamarun N, Zain M, Arief, Pazla R. 2018. Populations of rumen microbes and the in vitro digestibility of fermented oil palm fronds in combination with tithonia (Tithonia diversifolia) and elephant grass (Pennisetum purpureum). Pak J Nutr 17 (1): 39-45.

Jamarun N, Pazla R, Zain M, Arief. 2019. Comparison of in vitro digestibility and rumen fluid characteristics between the tithonia (Tithonia diversifolia) with elephant grass (Pennisetum Purpureum). IOP Conf Ser: Earth Environ Sci 287 (1): 1-6.

Jayanegara A, Aldi Y, Lilis K. 2019. Reduction of Proteolysis of high protein silage from moringa and Indigofera leaves by addition of tannin extract. Vet World 12 (2): 211-217.

Kennish MJ. 2000. Estuary restoration and maintenance: the national estuary program. CRC Press, Boca Raton, USA. 
Kitamura S, Anwar C, Chaniago A, Baba S. 1997. Handbook of mangroves in Indonesia; Bali \& Lombok. The development of sustainable mangrove management project, Ministry of Forest Indonesia and Japan International Cooperation Agency, Denpasar. [Indonesian]

Leng RA. 1991. Feeding strategies for improving milk production of dairy animals managed by small farmers in the tropics. Feeding dairy cows in the tropics. (eds) Speedy A, Sansoucy R. Proceedings of the FAO Expert Consultation held in Bangkok, Thailand, 82.

Little DA. 1986. The Mineral Content of ruminant feeds and potential for mineral supplementation in southeast Asia with particular reference to Indonesia. In: Dixon RM (ed). Proc. of the Fifth Annual Workshop of the Australian-Asia Ruminant Feeding System Utilizing Fibrous Agricultural Residues. 1985. Int. Dev. Prog. of Austr. Univ. and Colleges Limited (IDP), Canberra, Australia.

Mathius IW. 1988. Jenis dan nilai gizi hijauan makanan domba dan kambing di pedesaan Jawa Barat. Dalam: Prosiding Pertemuan Ilmiah Ruminansia. Jilid 2, Ruminansia Kecil. Cisarua, Bogor. [Indonesian]

Mc. Donald P, Edwards RA, Greenhalgh JFD, Morgan CA. 2010. Animal Nutrition. $7^{\text {th }}$ ed. Longman, New York.

Mc Dowell LR, Conrad, JH, Ellis GL Loosli JK. 1983. Minerals for grazing ruminants in tropical regions. Universitas of Florida and The Agency for International Development, USA.

Ningrat RWS, Zain M, Erpomen, Suryani H. 2018. Effects of supplementation of different sources of tannins on nutrient digestibility, methane production and daily weight gain of beef cattle fed an ammoniated oil palm frond based diet. Intl J Zool Res 14: 813.

NRC. 1989. Nutrient Requirement of Dairy Cattle. 7th Edition. National Academic of Science, Washington DC., USA.

NRC. 2001. Nutrient requirements of beef cattle: Seventh Revised Edition: Update 2000. Subcommittee on Beef Cattle Nutrition. Committee on Animal Nutrition. National Research Council, USA.

Nugroho P. 2008. Agribisnis ternak ruminansia Jilid 1 Untuk SMK. Direktorat Pembinaan Sekolah Menengah Kejuruan, Direktorat Jenderal Manajemen Pendidikan Dasar dan Menengah, Departemen Pendidikan Nasional, Jakarta. [Indonesian]

Nugroho RA, Sugeng W, Rudhi P. 2013.Studi kandungan bahan organik dan mineral (N, P, K, Fe dan $\mathrm{Mg}$ ) sedimen di kawasan mangrove Desa Bedono, Kecamatan Sayung. J Mar Res 2: 62-70.

Onwuka SK, Avwioro OG, Akpan MO, Ahmed Y. 2001. Distribution of cobalt, manganese, and iron in the skin and hair of West African dwarf sheep and goat in Nigeria. Afr J Biomed Res 4: 151-154.

Paengkoum P, Liang JB, Jelan ZA, Basery M. 2006. Utilization of steamtreated oil palm fronds in growing Saanen goats supplementation with energy and urea. Asian-Aust J Anim Sci 19 (11): 1623-1631.

Palmquist DL, Jenkins TC. 1980. Fat in lactation ration: a review. J Dairy Sci 63: 1-14.

Pazla R. 2018. Pemanfaatan Pelepah Sawit dan Titonia (Tithonia diversifolia) dalam Ransum Kambing Peranakan Etawa untuk Menunjang Swasembada Susu 2020. [Disertasi]. Universitas Andalas, Padang. [Indonesian]
Pazla R, Jamarun N, Zain M, Arief. 2018a. Microbial Protein synthesis and fermentability of fermented oil palm fronds by Phanerochaete chrysosporium in combination with tithonia (Tithonia diversifolia) and elephant grass (Pennisetum purpureum). Pak J Nutr 17 (10): 46270 .

Pazla R, Zain M, Ryanto I, Dona A. 2018b. Supplementation of minerals (phosphorus and sulfur) and Saccharomyces cerevisiae in a sheep diet based on a cocoa by-product. Pak J Nutr 17 (7): 329-335.

Pazla R, Jamarun N, Agustin F, Zain M, Arief, Cahyani NO. 2020. Effects of supplementation with phosphorus, calcium and manganese during oil palm frond fermentation by Phanerochaete chrysosporium on ligninase enzyme activity. Biodiversitas 21 (5): 1833-1838.

Prabowo A, Djajanegara A, Diwyanto K. 1997. Nutrisi mineral pada ternak ruminansia. Jurnal Litbang Pertanian 16 (2): 53-64. [Indonesian]

Preston TR, Leng RA. 1987. Matching ruminant production systems with available resources in the tropics and sub-tropics. The Technical Centre for Agricultural and Rural Co-operation (CTA). Wageningen, Netherlands.

Rahardian A, Lilik BP, Yudi S, Ketut W. 2019. Tinjauan historis data dan informasi luas mangrove Indonesia. Media Konservasi 24 (2): 163-78.

Richards DR, Friess DA. 2016. Rates and drivers of mangrove deforestation in Southeast Asia, 2000-2012. Proc Natl Acad Sci USA 113 (2): 344-349.

Standar Nasional Indonesia (SNI). 2017. Pakan konsentrat-Bagian 2 : Sapi Potong. Badan Standarisasi Nasional, Jakarta. [Indonesian]

Sudarmono AS, Sugeng YB. 2008. Edisi Revisi Sapi Potong. Penebar Swadaya, Jakarta. [Indonesian]

Suparjo. 2010. Diktat Laboratorium Makanan Ternak. Fakultas Peternakan Universitas Jambi, Jambi. [Indonesian]

Suyitman, Warly L, Rahmat A, Pazla R. 2020. Digestibility and performance of beef cattle fed ammoniated palm leaves and fronds supplemented with minerals, cassava leaf meal and their combinations. Adv Anim Vet Sci 8 (9): 991-996.

Tilley JMA, Terry RA. 1963. A two-stage technique for the in vitro digestion of forage crops. J Brit Grassl Soc 18 (2):104-111.

Tillman AD, Hartadi H, Reksohadiprojo S, Prawirokusumo S, Lebdosukodjo S. 1998. Ilmu Makanan Ternak Dasar. Gadjah Mada University Press, Yogyakarta. [Indonesian]

Tomlinson PB. 1986. The Botany of Mangroves. Cambridge University Press, Cambridge.

United Nations Environment Program. 2014. United nations environment program world conservation monitoring center. The Importance of Mangroves to People: A Call to Action. http://newsroom.unfccc.int/es/el-papel-de-la-naturaleza/la-onu-alertade-la-rapida-destruccion-de-los-manglares/.

Van Soest PJ. 1982. Nutritional ecology of the ruminant metabolism chemistry and forage and plant fiber. Cornell University, Oregon, USA.

Van Soest PJ, Robertson JB, Lewis BA. 1991. Methods for dietary fiber, neutral detergent fiber, and nonstarch polysaccharides in relation to animal nutrition. J Dairy Sci 74 (10): 3583-3597. 